\title{
半無限長の主防波堤と副防波堤によって形成される 港内波の波高と波向についての基礎的研究
}

\author{
椹 木 亨* 一 保雅 義**.今 井 昭 夫** \\ Basic Research on Directional Spectrum of Harbour Waves \\ Diffracted by Two Semi-Infinite Breakwaters
}

Toru SAWARAGI, Masayoshi KUBO and Akio IMAI

\begin{abstract}
Because ship motions are heavily affected by wave periods and wave directions, not only wave height but also wave periods and directions must be given in order to obtain the moored ship motions in a harbour. As the first step to obtain the directional spectrum in a harbour, a method for deriving directional spectrums of harbour waves diffracted by two semi-infinite breakwaters is proposed. Moreover, the accuracy of the approximate solution is improved by introducing new velocity potentials neglected in Takayama's method ${ }^{(1)}$.
\end{abstract}

\section{1. 緒 震}

従来，港湾は湾奥の比較的自然条件の穏やかな地域に位置していた。しかし高度経済成長以後，港湾は地域開 発のため外洋に面した所にも建設されて現在に至っている。このよらな港湾では自然条件が厳しいため，自然条 件の影響で倚役能率が低下することがある。港湾の機能性を表わす一つの考え方として港内静穞度がある。従来 より港内静穞度は波高で表わされているが，著者らは波高より係留船の船体運動で表わす方がより現実的である と考えている。係留船の運動を計算する場合, 波高も重要であるが, そのほかに波の周期と波向きも重要な要素

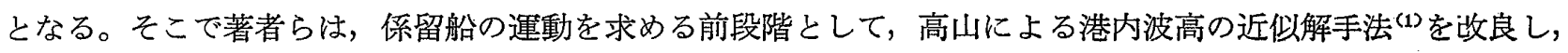
港内波の方向スペクトルを計算する手法の開発に取り組んだ。

港内波高に関しては, 従来より(1)数值波動解析 ${ }^{(2)}$ ，(2) Green 関数を用いる方法 ${ }^{(3)}$, (3)高山の近似解手法 ${ }^{(1) か ゙ あ ~}$ る。(1)と(2)は厳密解を求める手法であり, 計算精度が高いといら利点がある。しかし港内水域に入射波の波長の $1 / 10$ と $1 / 20$ 程度の間隔で計算点を設定しなければならない。従って小規模港湾では問題はないが，大規模港湾で は計算点が多くなり，必要な計算機容量の増大と計算時間が長くなる欠点を有する。(3)は今回著者らが用いた手 法であるが，近似解を求めるため(1)と(2)より計算精度は劣るが，実用上充分な精度が得られる。さらに計算点注 必要な数だけ自由に設定できるため，計算機容量も少なく計算時間も短い。

一方港内波の方向スペクトルを求める手法としては桑島の方法 ${ }^{(4)}$ がある。しかしこれは波向きを求める方法 が明確にされて抢らず，さらに開口防波是の配置によって生じる種々の速度ポテンシャルに対する考慮がなされ ていない。

そこで本報告においては主副防波堤のすべての組み合せを考慮し，さらに反射波を 3 回まで考慮することによ り近似解の精度の向上に努めるとともに，波高だけでなく波向きをも表わす方向スペクトルを求めた。

* 正会員 大阪大学工学部 (吹田市山田丘 2-1)

** 正会員 神戸商船大学 (神戸市東灘区深江南町 5-1-1) 


\section{2. 回折波の計算手法}

\section{1 規則波による回折波}

2.1.1 半無限長防波堤による回折波の波高と 波向

本計算を行うに当り，流体，流体運動および境界 条件として次の仮定を行う。

(1) 流体は非圧縮性である。

（2）流体運動は非回転運動である。

（3）相対波高および水面勾配は十分小さい。

（1）水深は一様で，水底での水の流出入はない。 このような仮定の下で，図1のよらな半無限防波堤 に $\alpha$ の角度で波が入射してくる場合の防波堤付近の 速度ポテンシャル法，防波堤先端を原点とする植座 標を $(r, \theta) ， k=2 \pi / L ， L$ は大射波の波長，防波湜の

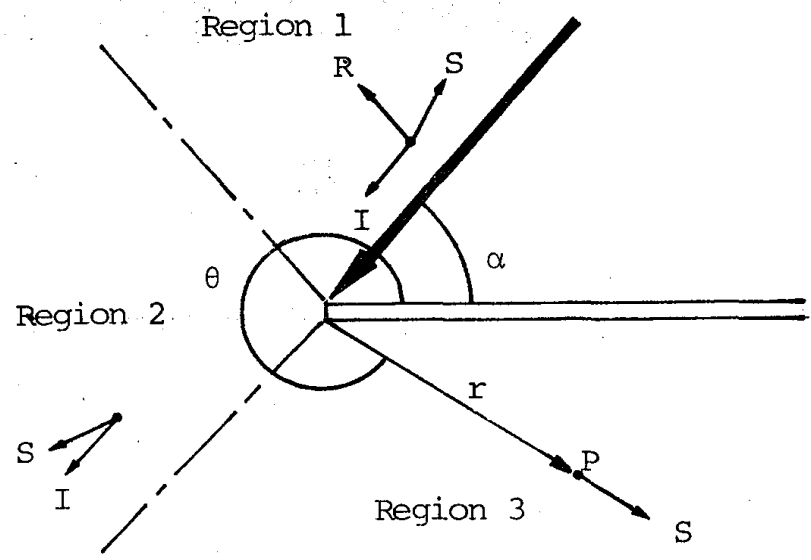

図 1 半無限防波堤による波の回折におおる座標 反射率を $K_{r}$ とすると次式で表わされる。

$$
\begin{aligned}
& \phi(r, \theta)=\frac{1}{\sqrt{2}} \exp \left[\mathrm{i}\left\{k r \cos (\theta-\alpha)+\frac{\pi}{4}\right\}\right] \\
& \times\left[\left\{C\left(\gamma_{1}\right)+\frac{1}{2}\right\}-i\left\{S\left(\gamma_{1}\right)+\frac{1}{2}\right\}\right] \\
&+\frac{K_{r}=}{\sqrt{2}} \exp \left[i\left\{k r \cos (\theta+\alpha)+\frac{\pi}{4}\right\}\right] \\
& \times\left.\times\left\{C\left(\gamma_{2}\right)+\frac{1}{2}\right\}-i\left\{S\left(\gamma_{2}\right)+\frac{1}{2}\right\}\right]
\end{aligned}
$$

ここにC $(\gamma)$ と $S(\gamma)$ は次式の Fresnel 積分で与えられる。

$$
C(\gamma)=\int_{0}^{\gamma} \cos \frac{\pi}{2} x^{2} d x, S(\gamma)=\int_{0}^{\gamma} \sin \frac{\pi}{2} x^{2} d x
$$

また $\gamma_{1}$ と $\gamma_{2}$ は次式にて与えられる。

$$
\gamma_{1}=\sqrt{\frac{4 k r}{\pi}} \cos \frac{\theta-\alpha}{2}, \quad \gamma_{2}=\sqrt{\frac{4 k r}{\pi}} \cos \frac{\theta+\alpha}{2}
$$

反射率が 1 の場合の式(1)は Sommerfeld によって求められた厳密解である。この解は図 1 中の計算領域每につぎ のように変形寸ることが可能である(1)。

まず $0 \leqq \theta<\pi-\alpha$ の領域 I，つまり大射波と防波堤による反射波が存在する領域では，式(1)は次式のように変 形できる。

$$
\begin{aligned}
\phi(r, \theta)= & \exp [i k r \cos (\theta-\alpha)] \\
+ & \frac{1}{\sqrt{2}} \exp \left[i\left\{k r \cos (\theta-\alpha)+\frac{\pi}{4}\right\}\right] \\
& \times\left[\left\{C\left(\gamma_{1}\right)-\frac{1}{2}\right\}-i\left\{S\left(\gamma_{1}\right)-\frac{1}{2}\right\}\right] \\
+ & K_{r} \exp [i k r \cos (\theta+\alpha)] \\
+ & \frac{K_{r}}{\sqrt{2}} \exp \left[i\left\{k r \cos (\theta+\alpha)+\frac{\pi}{4}\right\}\right] \\
& \times\left[\left\{C\left(\gamma_{2}\right)-\frac{1}{2}\right\}-i\left\{S\left(\gamma_{2}\right)-\frac{1}{2}\right\}\right]
\end{aligned}
$$

上式において第1 項は入射波を，第 3 項は反射波を示す。また第 2 項は入射波に伴う散乱波を，第 4 項は反射波 に伴ら散乱波を示す。ここで散乱波とは波が防波堤先端に当ることにより発生する波で防波堤先端から放射状に 進行する。以上より入射波，反射波拉よび散乱波の進行方向は図 1 の領域 1 の I， R，Sで示される方向となる。

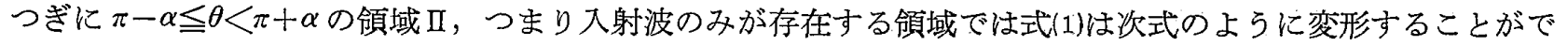
きる。 


$$
\begin{aligned}
\phi(\boldsymbol{r}, \theta) & =\exp [i k r \cos (\theta-\alpha)] \\
+\frac{1}{\sqrt{2}} & \exp \left[i\left\{k r \cos (\theta-\alpha)+\frac{\pi}{4}\right\}\right] \\
& \times\left[\left\{C\left(\gamma_{1}\right)-\frac{1}{2}\right\}-i\left\{S\left(\gamma_{1}\right)-\frac{1}{2}\right\}\right] \\
+\frac{K_{r}}{\sqrt{2}} & \exp \left[i\left\{k r \cos (\theta+\alpha)+\frac{\pi}{4}\right\}\right] \\
& \times\left[\left\{C\left(\gamma_{2}\right)+\frac{1}{2}\right\}-i\left\{S\left(\gamma_{2}\right)+\frac{1}{2}\right\}\right]
\end{aligned}
$$

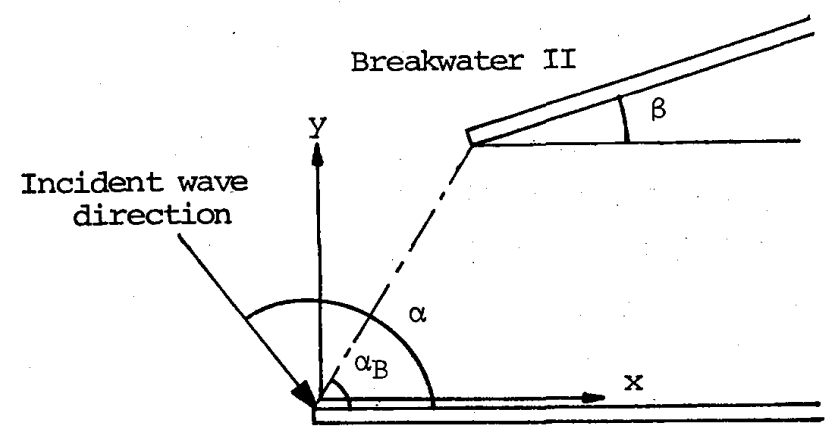

Breakwater I

図 2 防波堤の配置と座標 よる散乱波，第 3 項は反射波による散乱波である。この 領域での入射波と散乱波は I と Sの方向へ進行する。

最後に $\pi+\alpha<\theta<2 \pi$ の領域 $\mathrm{II}$, つまり入射波も反射波も存在しない 領域での速度ポテンシャルは式(1)と なる。ここで第 1 項は入射波に伴う 散乱波, 第 2 項は反射波に伴う散乱 波である。

\section{1 .2 防波奜配置と入射波何 の組み合せ}

著者らが対象とする水域は図 2 の ような 2 本の半無限防波罡によって 構成される水域である。ここで防波 堤 I は必ず水平に配置される。さら に防波堤 I とIIの先端を結んだ線と 防波堤 I とのなす角を $\alpha_{B}$, 防波堤 II が防波堤 I となす角を $\beta$ ， 入射波の

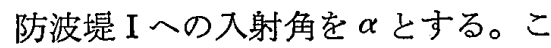
れらの角はいずれも反時計回りに測 るものとする。また $x, y$ 座標の原 点は防波堤 $\mathrm{I}$ の先端とし，防波堤 $\mathrm{I}$ に沿って $x$ 軸を，防波堤 $\mathrm{I}$ と鉛直に $\boldsymbol{y}$ 軸をとる。

実際の港湾では防波堤配置は一定 ではなく，さまざまな配置となる。 そこで防波堤の配置と波向から考え て図 3 のような 7 つの場合について 回折波の計算法を確立した。

CASE25：入射波が防波堤 Iに反 射され，反射波が港外 方向一向う。

CASE 1 ：入射波が一部港内に入 り，防波堤 Iに反射さ れ，反射波が港外方向 一向う。

CASE 2 ：入射波が防波堤 I で反

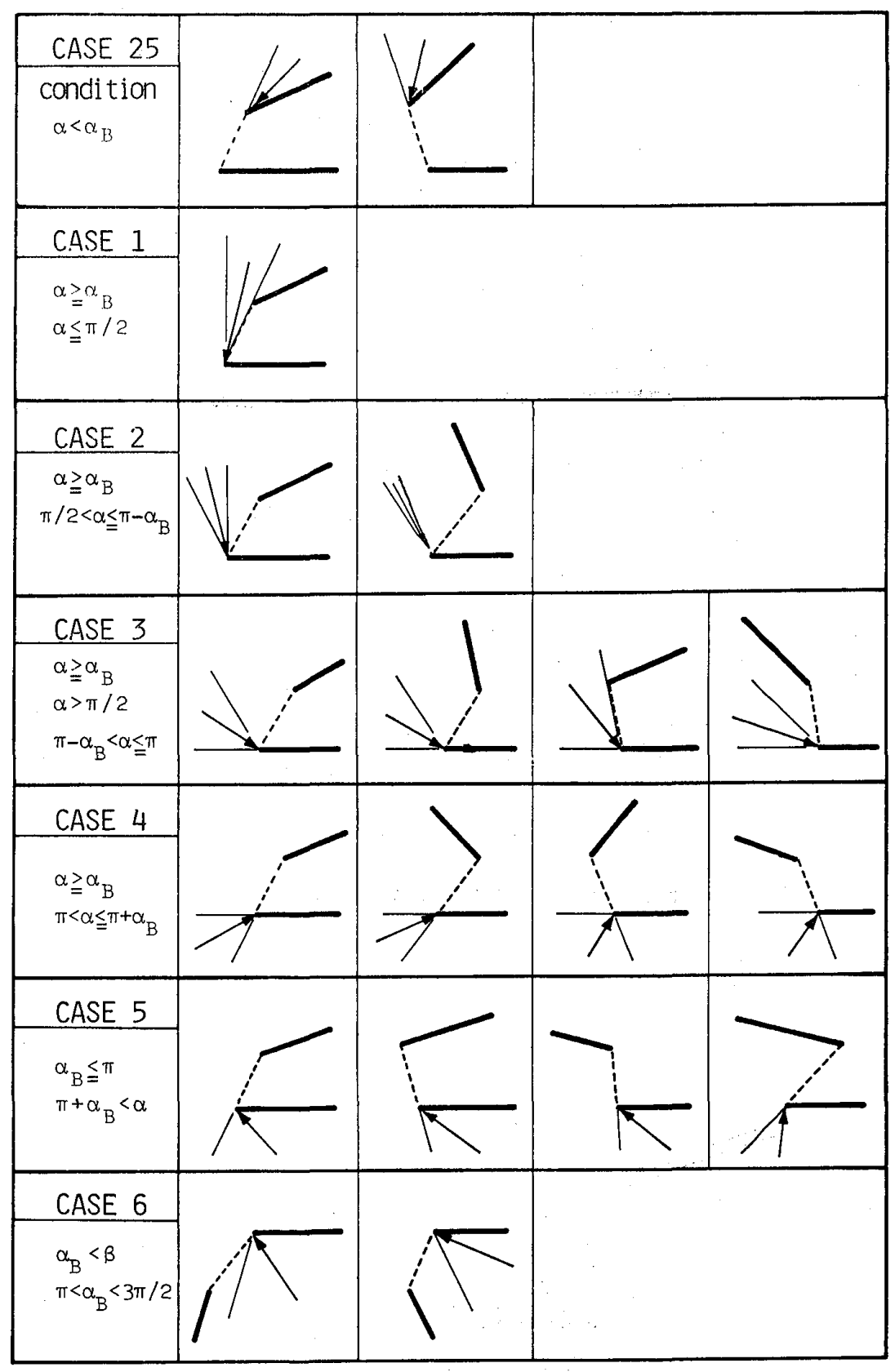

図 3 防波堤配置と入射波向の組み合せ 


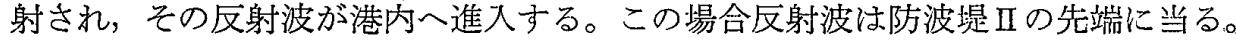

CASE 3 ：入射波が防波堤 I に反射され，その反射波が港内に侵入する。この場合の反射波注防波堤川の先端 には当らない。

CASE $4 \cdots$ 入射波が值接港内に侵入する。

CASE 5 ：入射波が防波堤 I に反射され，その反射波は港外方向八向う。

CASE 6 ：防波堤开が防波堤 I の下に位置し，入射波は直接港内に侵入する。

以上の組み合せの内，CASE 1 〜 5 は高山の近似解手法において考慮されていた。しかしこれだけでは組み合せ が不足するためCASE 6 を新たに加えた。さらに高山の近似解手法では CASE25 計算する場合，CASE 5 にお いて防波堤 I とI を逆にして計算していたが，混乱を避けるため著者らは CASE25を付け加えた。上記のCASE 25〜 6 以外にも主・副防波堤の組み合せは存在するが，それらに対しては CASE25〜 6のいずれかを裏返しに見 て計算することで対応している。
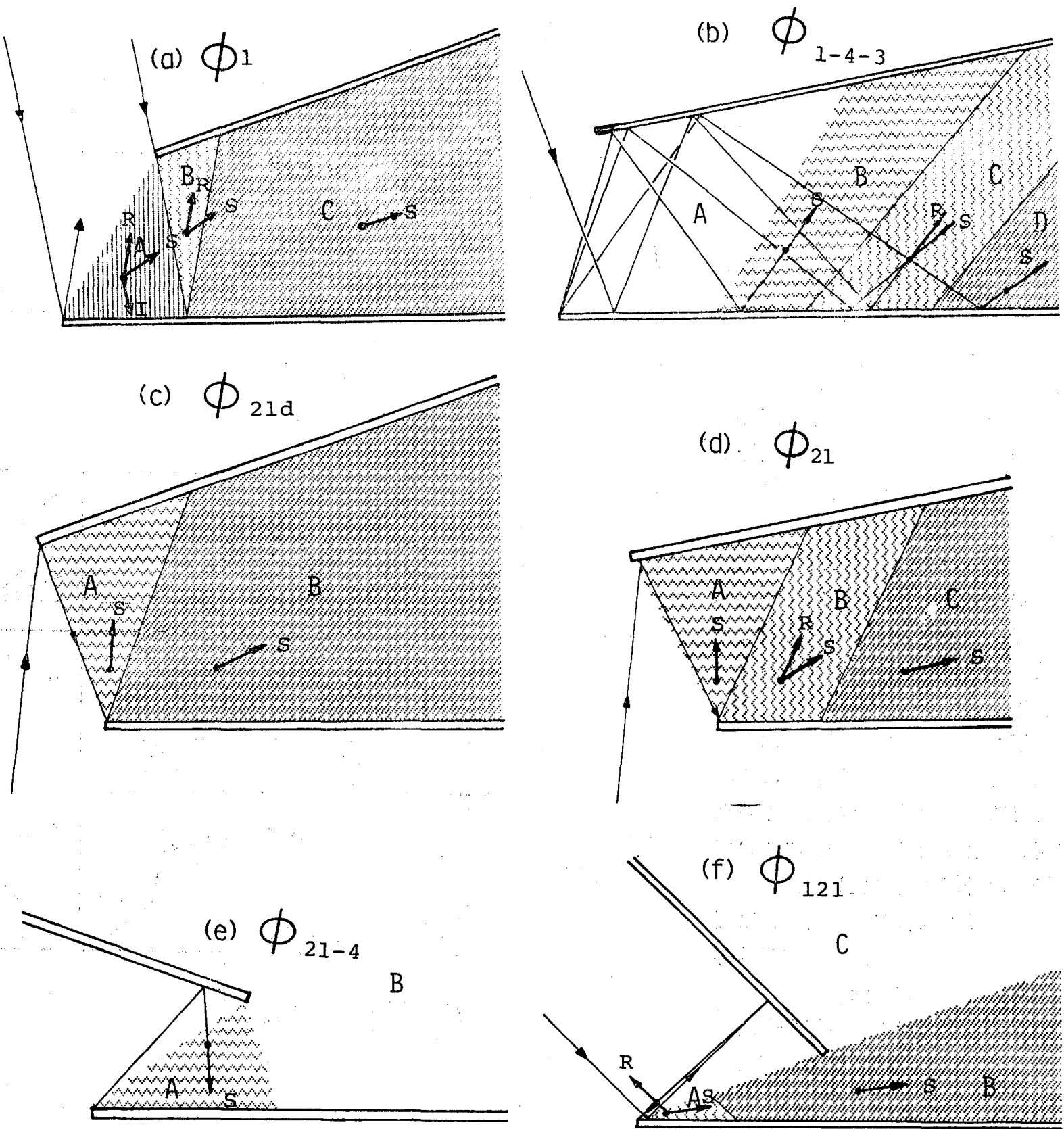

(d) $\phi_{21}$
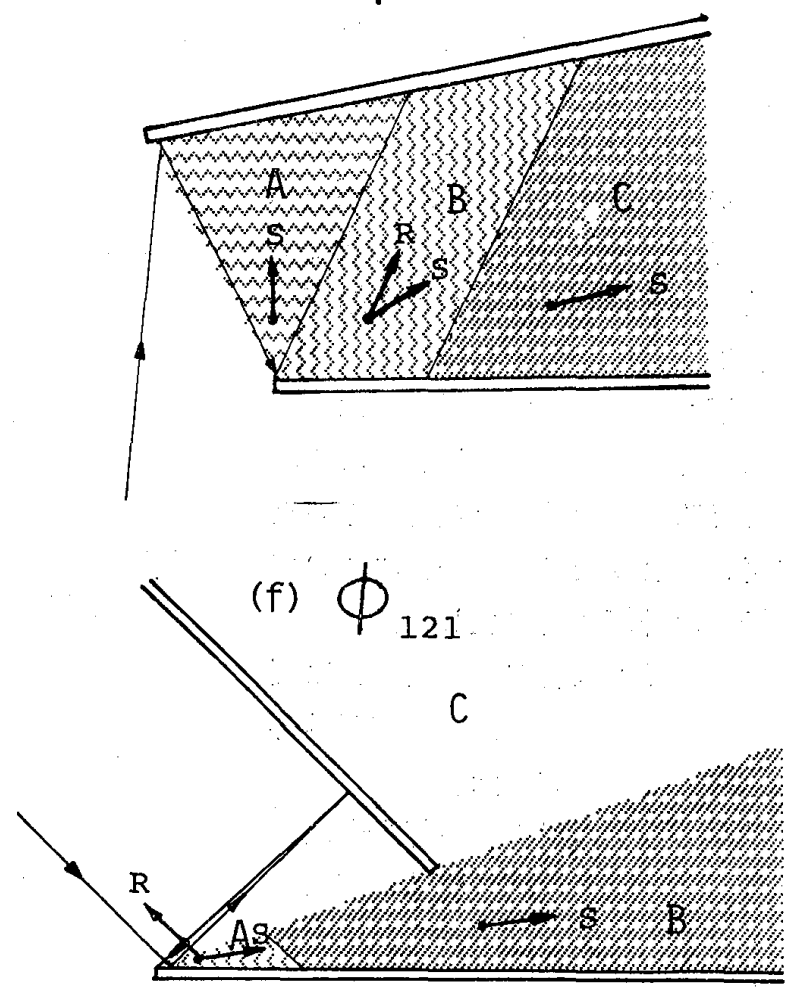

図 4 防波堤によって生じる速度ポテンシャル 


\subsection{3＼cjkstart防波堤によって生じる速度ポテンシャル}

先に述べたような 2 つ防波堤の配置と入射波向との関係により，発生する速度ポテンシャルの種類が異なる。 そこで以下に防波是 I から発生する速度ポテンシャルについて述べる。防波堤且から発生する速度ポテンシャル は防波堤 I から発生する速度ポテンシャルと同様な手順で得られるので，ここでは説明を省略する。

まず入射波が防波堤 I の先端に当って発生する速度ポテンシャルを $\phi_{1}$ と呼び，これを図 4 -(a)k示す。この場 合, 入射波, 反射波, 散乱波の有無により A，B㧍よびCの 3 つの領域に分けられる。各領域内の計算点での記 号 $\mathrm{I} ， \mathrm{R} ， \mathrm{~S}$ はそれぞれ入射波，反射波及び散乱波を表わし，矢印はそれぞれの成分波の波向きを表わしてい る。これからも明らかなように入射波と反射波は幾何光学的に波向きを与え，散乱波は防波堤の先端から放射状 に伝播するものとして防波是先端と計算点とを結んだ方向で与える。

防波堤 I の先端から発生した散乱波は防波堤 IIで反射され新しい速度ポテンシャルを発生するが，これを $\phi_{1-4}$ と呼ぶ。この波は防波堤 I で再度反射される。このようにして生じた波の速度ポテンシャルが $\phi_{1-4-3}$ であり図 4 一(b)に示す。領域Cの反射波は入射波が防波堤 I，II，I の順に当って生じたものである。領域 $\mathrm{B}$ とD洌乱波 のみしか存在しないという意味においては同じであるが，式(1)，(1)，(5)で示したように散乱波の表示式は必ずし も同じではない。そこで散乱波のみしか存在しない領域であっても, 表示式が異なる場合には別の領域として婊 示する。これは以下の領域分けにおいても同様である。

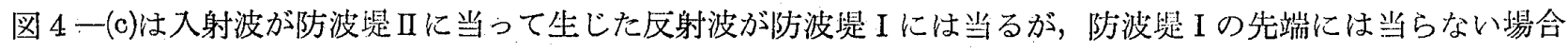

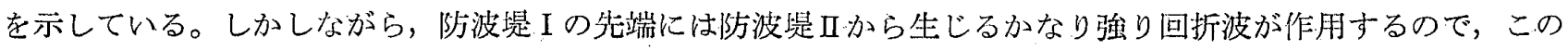
回折波を防波堤 Iへの入射波と見なした時に坐じ

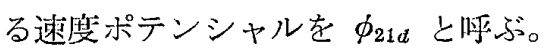

図 4-(d)は防波堤且の先端に当った反射波が防 波鼠 I の先端に当る場合で，この時生じる速度ポ テンシャルを $\phi_{21}$ と呼ぶ。

$\phi_{21}$ の散乱波が防波堤 II で反射して生じる速度 ポテンシャルを $\phi_{21-4}$ と呼び，これを図 4 -(e) に 示す。この場合領域Bでは $\phi_{21-4}$ 注存在しない。

図 4-(f)は，防波堤 I で生さた反射波が，防波 堤 II 当り，さらにその反射波が防波堤 I の先端 に当る場合である。この場合の速度ポテンシャ ルを $\phi_{121}$ と呼ぶ。領域C は防波堤 Iの影になるの

裴 1 各ケースに扮いて考慮した速度ポテンシャルについて

\begin{tabular}{|c|c|}
\hline CASE 25 & $\Phi_{2}, \Phi_{2-3}, \underline{\Phi_{210}}$ \\
\hline CASE 1 & $\phi_{1}, \phi_{2}, \underline{\phi_{2-3}}, \underline{\phi_{1-4}}, \phi_{12 a}, \underline{\phi_{21 a}}$ \\
\hline CASE 2 & $\begin{array}{l}\phi_{1}, \phi_{2} \\
\phi_{21-4}, \underline{\phi_{121}}\end{array}, \underline{\phi_{1-4}}, \phi_{12}, \underline{\phi_{21}}, \underline{\phi_{12-3}}$, \\
\hline CASE 3 & $\begin{array}{l}\Phi_{1}, \phi_{2}, \frac{\phi_{2-3}}{\phi_{21-4}}, \underline{\phi_{1-4}}, \underline{\phi_{1-4-3}}, \underline{\phi_{21}},\end{array}$ \\
\hline CASE 4 & 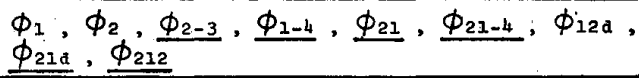 \\
\hline CASE 5 & $\phi_{1}, \underline{\phi_{1-4}}, \underline{\phi_{21}}, \phi_{21-4}, \phi_{12 d}, \phi_{212}$ \\
\hline CASE 6 & $\phi_{1}, \phi_{2}, \phi_{12}, \underline{\phi_{21}}, \phi_{12 \mathrm{~d}}, \underline{\phi_{21 d}}, \underline{\phi_{121}}$, \\
\hline
\end{tabular}

で， $\phi_{121}$ は存在しないものとして扱う。

以上のように防波堤の配置と波向きに よって種々の速度ポテンシャルが発生す るが，これを各ケ一ス毎にまとめて表 1 に示している。表1でアンダーラインの 付いた速度ポテンシャルが今回新たに追， 加した速度ポテンシャルである。

このようにして港内計算点での速度ポ テンシャルが求まるが，これをすべて合 計したものが, 各点での速度ポテンシャ ルである。入射波高で無次元化された港 内での相対波高はこの合計された速度ポ テンシャルの絶対值で与えられるので, 港内をかなり密に分割してそれらの点で 上記の速度ポテンシャルの計算を行え ば，波高分布図が描かれる。一方，上記

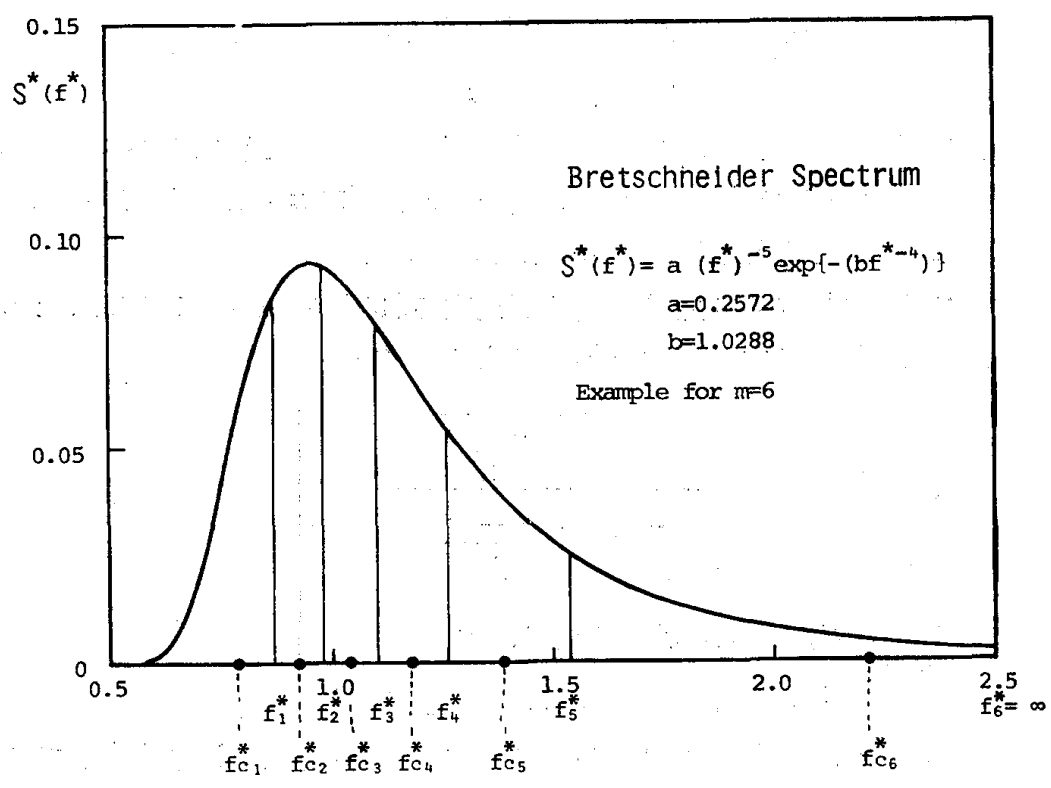

図 5 本計算に用いた周波数スペクトル 
で求められる波向きは当然のことながら全方位にわたる連続量となるが，後述の方向スペクトルの計算では10度 毎に方向を分割するので，回折計算で得られる波のエネルギーは36方位に比例配分している。

2.2 不規則波による回折波について

2.2.1 入射波の方向スペクトル

奏際の港には，いろいろな周期と波向きを持つ不規則波が侵入する。このように周波数と方向を包含したスぺ クトルを一般に方向スペクトルと呼ぶ。今この港内侵入波の方向スペクトルを $D_{o}^{*}\left(f^{*}, \alpha\right)$ で表わすと，これは 次のように分解される。

$D_{o}^{*}\left(f^{*}, \alpha\right)=G\left(f^{*}, \alpha\right) S^{*}\left(f^{*}\right)$

ここに $S^{*}\left(f^{*}\right)$ 汇無次元周波数スペクトル， $f^{*}$ 法有義周期 $T_{1 / 3}$ による無次元周波数， $G\left(f^{*}, \alpha\right)$ は方向関数 と呼ばれるものである。

周波数スペクトルとしてはいろいろな形のものが提案されているが, 本論では図 5 に示すように Bretschneider のスペクトルを有義波高 $H_{1 / 3}$ の 2 乗と有義周期 $T_{1 / 3}$ の積で無次元化したスペクトルを用いている(5)。

$$
\begin{gathered}
\left.S^{*}\left(f^{*}\right)=S(f) / H_{1 / 3}{ }^{2} \cdot T_{1 / 3}\right) \\
=a f^{*-5} \exp \left\{-\left(b f^{* 4}\right)\right\} \\
a=0.2572, \quad b=1.0288
\end{gathered}
$$

実際の計算に当ってはスペクトルを分割して代表的な周期に゙拉いて計算を行うことになるが，今回は分割された 各周波数带のエネルギーが等しくなるように分割を行っている。この場合の分割周波数 $f_{n}{ }^{*}$ および各成分波の代 表周波数 $f_{\mathrm{c} n}{ }^{*}$ 注次式にて与兄らる ${ }^{(5)}$ 。

$$
\begin{aligned}
& f_{n}^{*}=1.0071 /{ }^{4} \sqrt{\ln (m / n)} \\
& f_{c n}^{*}=\frac{1}{0.9} \sqrt{2.9124 m\left[\Phi\left(\sqrt{\left.2 \ln \left(\frac{m}{n-1}\right)\right)}-\Phi\left(\sqrt{2 \ln \left(\frac{m}{n}\right)}\right)\right]\right.}
\end{aligned}
$$

ここにmは周波数の分割個数， $n$ は分割の番号， $\Phi$ は誤差関数で次式で与えられる。

$$
\Phi(t)=\int_{0}^{t} \frac{\exp \left(-z^{2} / 2\right)}{\sqrt{2 \pi}} d z
$$

図 5 は分割個数 6 の場合の分割周波数および代表周波数を表わしている。

無次元周波数スペクトルを全周波数領域で積分すると $1 / 16$ になるので, 各成分波のスペクトル $\overline{S^{*}}\left(f_{\mathrm{cn}}^{*}\right) \cdot$ は次 式にでちられる。

$$
\bar{S}^{*}\left(f_{c n}^{*}\right)=\frac{1}{16 m \triangle f_{n}^{*}}
$$

ここに周波数帯域 $\triangle f_{n}^{*}$ は次式で与えられる。

$$
\triangle f_{n}^{*}=f_{n}^{*}-f_{n-1}^{*}, \quad 1 \leqq n \leqq m
$$

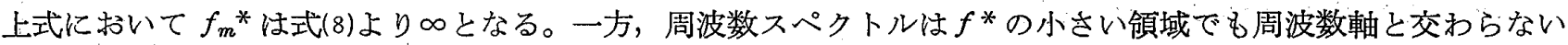
ため $f_{0}^{*}$ は決め難いが，今回㤬波数の分割数 $m$ を12としているので, $f_{c 1}^{*}$ でのスペクトル $\bar{S}^{*}\left(f_{c 1}^{*}\right)$ と $S^{*}\left(f_{c 1}^{*}\right)$ とが等しくなるよらに $f_{0}^{*}=0.66$ としている。

方向関数も種々の型式のものが提案されているが，ここでは光易によって提案された方向関数を用いる(6。す なわち，次式で方向関数を与えるものとする。

$$
\begin{aligned}
& G\left(f^{*}, \alpha\right)=\frac{\cos ^{2 s}\left(\frac{\alpha-\bar{\alpha}}{2}\right)}{\int_{\alpha_{\min }}^{\alpha_{\max }} \cos ^{2 s}\left(\frac{\alpha-\bar{\alpha}}{2}\right) d \alpha} \\
& S=\left\{\begin{array}{l}
S_{\max }\left(1.05 f_{n}^{*}\right)^{-2.5}, 1.05 f_{n}^{*}>1 \\
S_{\max }\left(1.05 f_{n}^{*}\right)^{5}, 1.05 f_{n}^{*} \leqq 1
\end{array}\right\}
\end{aligned}
$$

ここに $S$ は波の方向集中度パラメーターで， $S_{\max }$ は卓越周波数での波の方向集中度パラメ一タ一で以下の值を使 用するものとする。 


$\left.\begin{array}{ll}S_{m a x}=10 & : \text { 風波, } \\ S_{\max }=25 & \text { : 波形勾配の大きならねり } \\ S_{m a x}=75 & \text { : 波形勾配の小さいらねり }\end{array}\right\}$

さらに $\bar{\alpha}$ は不規則侵入波の主方向であり， $\alpha$ は個々の成分波の方向を示す。図 6 は $\alpha_{\max }=180^{\circ}, \alpha_{\min }=-180^{\circ}$ に おける方向関数の例を示している。この場合には式(12)の 方向関数の分母はガンマー関数 $\Gamma$ 它用いて $\pi \cdot 2^{1-2 S} \Gamma(2 S$ $+1) / \Gamma^{2}(S+1)$ で与えられる(6)。しかしながら防波堤 の方向と波向きによっては $\alpha_{\max }$ が $180^{\circ}$ よりさく， $\alpha_{\min }$

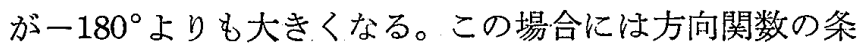
件 $\int_{\alpha_{\text {min }}}^{\alpha_{\text {max }}} G\left(f^{*}, \alpha\right) d \alpha=1$ 定満足するように, 式(12)で与 えている。以上で入射波の方向関数は与えられるが，計 筧に当っては等間隔に方向分制を行っている。

\section{2 .2 回折波の方占スペクトル}

以上で入射波の方向スペクトルが決められたので，こ の成分波を規則波と見なして，前述の回折計算を行え ば，回折後の成分波のエネルギーと波向きが求められ る。今周期が $f_{c n}{ }^{*}$ ，波向きが $\alpha_{i}$ の入射成分波が，回折 後 $\alpha_{j}(j=1,2, \cdots M)$ の波向きをもつ $\phi_{j}$ なる速度ポテ ンシャルを生じたとすれば，回折後の速度ポテンシャル $\phi_{a}$ は次式にて与えられる。

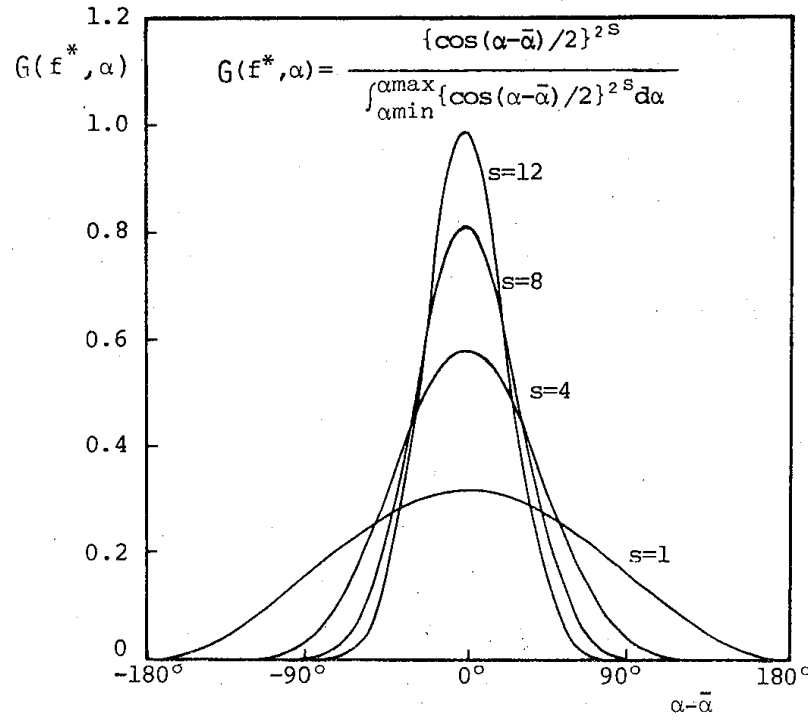

図 6 光易による方向スペクトル

$$
\phi_{d}=\sum_{j=1}^{M} \phi_{j}\left(f_{c n}^{*}, \alpha_{i}, \alpha_{j}\right)
$$

これは回折後に $M$ 個の波向きが生じたことを示寸。この場合回折係数は速度ポテンシャルの絶対值で与えられる ので，結局回折後の方向スペクトル $D^{*}\left(f_{e n}^{*}, \alpha_{k}\right)$ は次式で与えられる。

$$
D^{*}\left(f_{c n}^{*}, \alpha_{k}\right)=\sum_{i=1}^{N}\left|\phi_{k}\left(f_{c n}^{*}, \alpha_{i}, \alpha_{k}\right)\right|{ }^{2} D_{o}^{*}\left(f_{c n}^{*}, \alpha_{i}\right)
$$

ここにNは方位の分割個数である。

\section{3. 計 算 例}

今回，高山によって開発された港内波高の近似 解手法を改良するために新しい種々の速度ポテン シャルを導入して解の精度向上に努めたが，つぎ に両手法により港内波高を計算することにより雨 者の比較を行う。

図 7 は 2 本の平行な防波堤があって，第 1 防波 堤から $\alpha=270^{\circ}$ で単一方向の規則波が侵入する場 合の回折係数 $K_{d}$ の計算例である。この回折係数

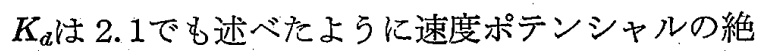
対值で与えられる。この防波堤配置と入射波向は CASE 5 に相当する。高山の方法では表 1 より $\phi_{1}$ と $\phi_{12 a}$ が考慮されるが著者らの方法ではそれ以 外に $\phi_{1-4}$ を新たに考慮している。この例では新た に考慮した速度ポテンシャルが少く，かつ小さい ために，両者の差はさほど顕著ではないが，今回 の計算波高の方が高山の計算波高よりも若干篇密

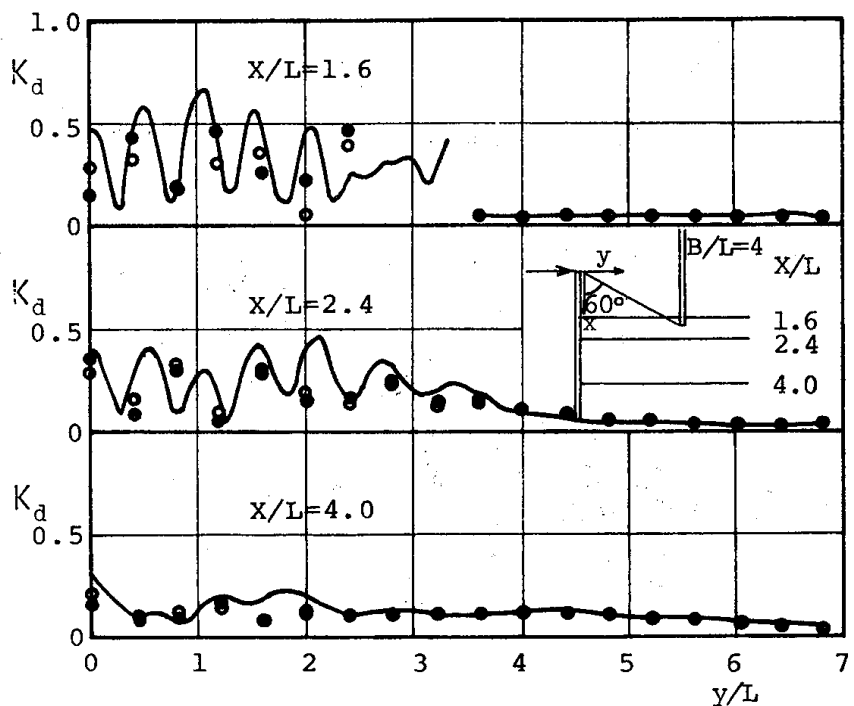

図 $7 \alpha=270^{\circ}, \alpha_{B}=60^{\circ}, \beta=180^{\circ}$ に打数值波動解 析(一), 高山の方法 $(○)$ および著者らの方法 による回折係数の比較 
解に近くなっている。

図 8 は波の入射角が $180^{\circ}$ よりも大きく，波が直接港内 に侵入するCASE 4 の波高分布の計算例である。高山の 方法では $\phi_{1}, \phi_{2}$ そして $\phi_{12 a}$ が考慮されるが，著者らの 方法ではそれ以外に，防波堤川の先端で生じる散乱波が 防波堤 I で反射して生じる $\phi_{2-3}$, 防波堤 I の先端で生じ る散乱波が防波堤 II で反射して生じる $\phi_{1-4}$, 防波堤 II 反射波が防波是 I $の$ 先端に当って生じる $\phi_{21}, \phi_{21}$ の散乱

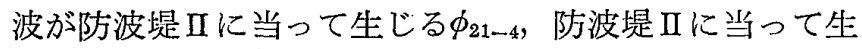
じた回折波が防波堤 I の先端に当って生じる $\phi_{21 d}$, 防波 堤 IIの反射波が防波是 I に当り，更にその反射波が防波 堤 Пの先端に当って生じる $\phi_{212}$ といった 6 個の新しい速 度ポテンシャルを考慮している。これらの速度ポテンシ ヤルのらち $\phi_{21} ， \phi_{212}$ はかなり強いポテンシャルなので, これを無視することは好ましくない。眓 8 に打いて著者

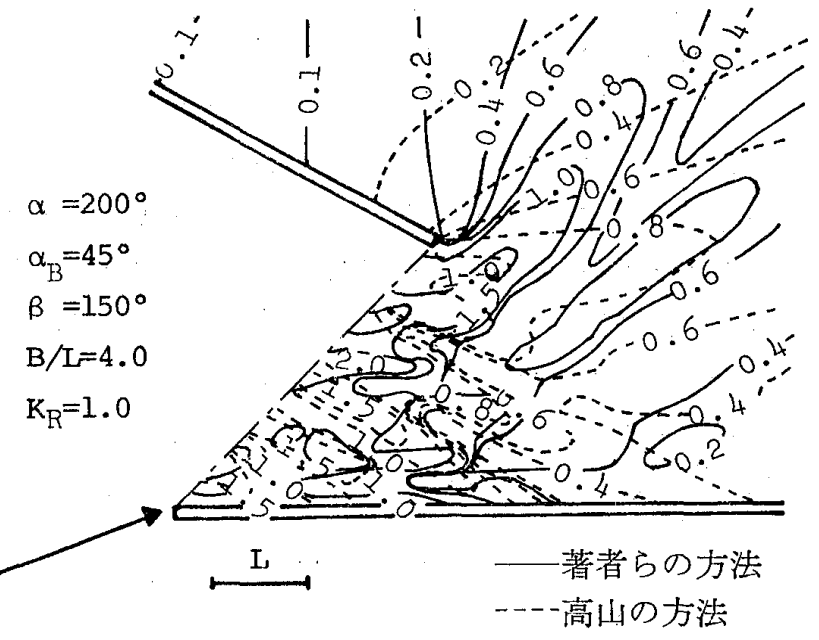

図 8 速度ポテンシャルの数の違いによる波高 分仿の違いについて らの方法で求めた波高が高山の方法で求めた波高よりも港内側で大きく，かつ波高の卓越方向が異なるのも上記 速度ポテンシャルの影響と考えられる。

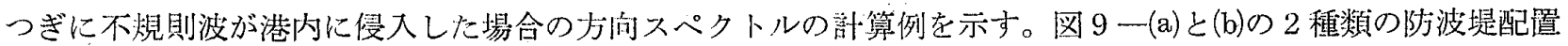
に刘して，同じ主方向を持つ波が港に侵人する場合の颜算例を示す。この場合の侵入波の方向スペクトルは図 9 一(c)で与えられる。この場合の方向関数は土90の籁囲で与えている。

図 9-(a)の黑丸は註䈍点を示すが，この点での方向スペクトルは図 9 -(d)で与えられる。この場合の波は防波 堤 Пからの回折波のみで，波向きの分布幅も小さく，かつスペクトルも小さいのがわかる。一方図 9 一(b)の計算

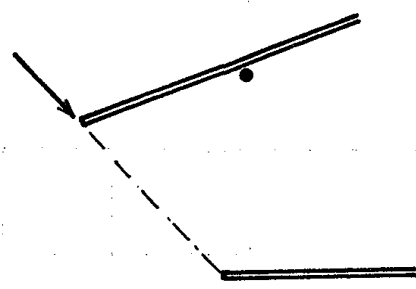

(a)

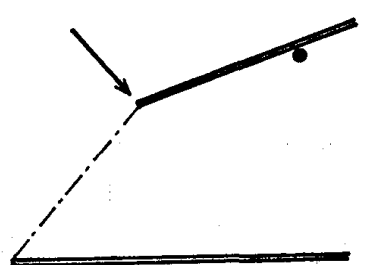

(b)

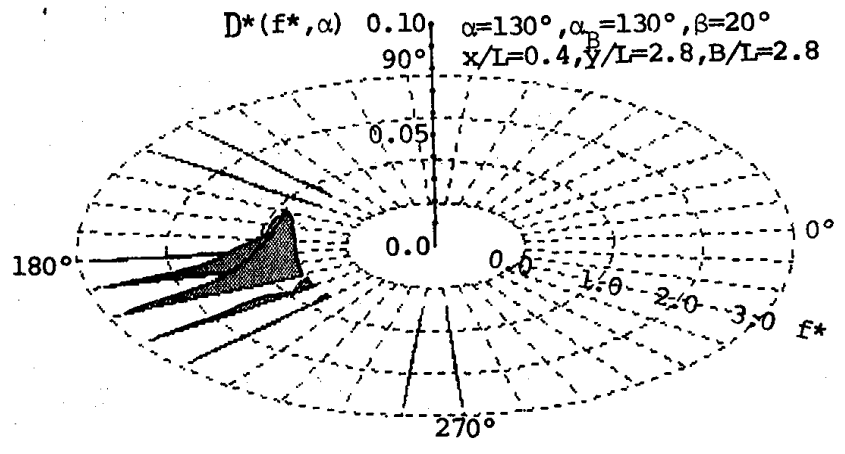

(d)

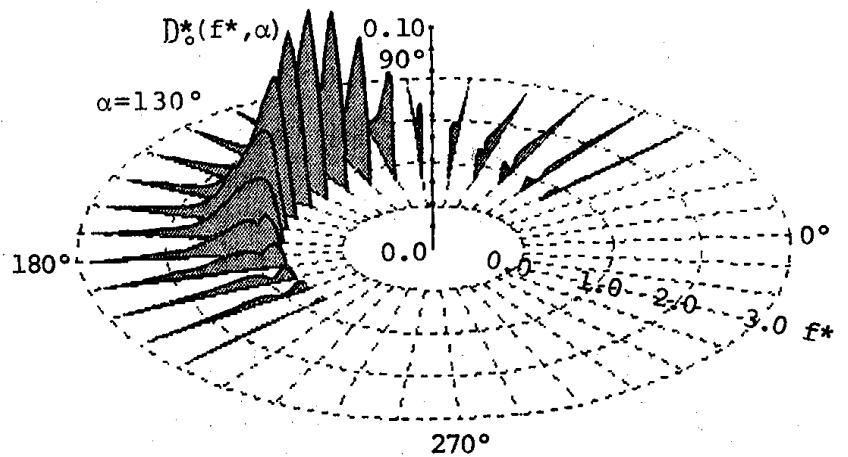

(c) Directional spectrum of incident wave

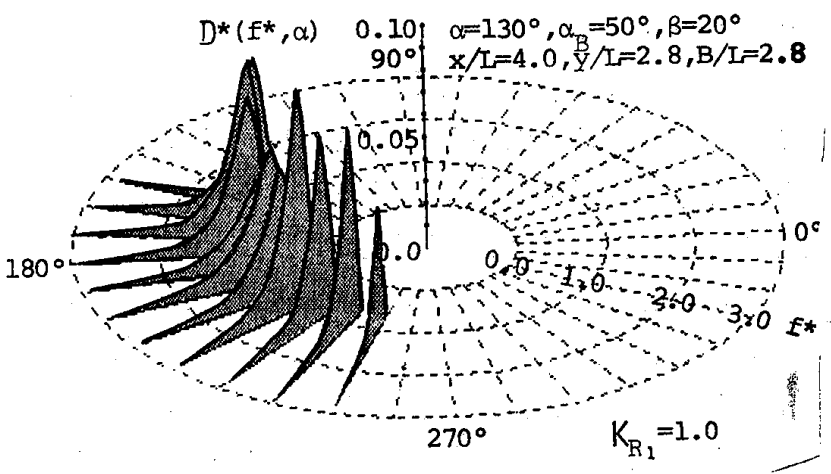

(e)

図 9 港内での方向スベクトルの計算例 $\left(S_{m a x}=10\right)$ 
点での方向スペクトルは図 9 -(e)で与えられる。この場合の防波堤 I は図 9 -(a)の場合の防波堤 I よりも長い。 この防波堤 I の延長分で生でた反射波のため，先に述べたような種々の速度ポテンシャルが発生し，図 9 -(e)に 示すように波向分布の幅む広く，スペクトルも大きくなっている。これ注一計算例に過ぎないが，防波堤を延長 することが常に港内波を小さくするここにはならない事は注意すべき事である。

\section{4. 結 論}

港内倸留船の運動を求めるためには港内波は波高だけでなく，方向スペクトルで与えなければならない。その ため，回折波を入射波，反射波，散乱波に分離し，それぞれの方向に波向きを与えることにより港内波の方向ス ペクトルを導びく方法を提案した。また高山の方法では無視されていた種々の速度ポテンシャルを新をに導入し て近似解の精度の向上に努めた。今回は 2 本の防波堤のみを㘷えたが，今後港内側に接壁や笑堤等がある場合に ついても計算可能な手法にしていく予定である。本研究を行うに当り種々有益な御助言を頂いた神戸商船大学・ 井上篤次郎教授に梁く謝意を表わします。

なお，この研究の一部は文部省科学研究費自然災害特別研究(1)（神戸商船大学久保雅義助教授代表）によった ことを付記し謝意を表する次第である。

\section{参 考 文 献}

（1）高山知司：波の回折と港内波高分布に関する研究，京都大学学位論文，1981.

（2）谷本勝利, 小舟浩治，小松和彦：数值波動解析法による港内波高分布の計算，港湾技術研究所報 告，第 14 巻，第 3 号，pp, 35 58, 1975.

(3) Lee, J.J. : Wave induced oscillation in harbours of arbitrary shape, Calif. Inst. of Tech., 1970.

（4）桑島 進：港内侵入波の計算について，日本航海学会論文集，54号，pp. 83 91, 1976.

（5）永井康平：不規則な海の波の屈折㧍よび回折の計算，港湾技術研究所報告，第 11 巻，第 2 号，pp. $47 \sim 119$, 1972 .

（6）光易恒，水野信二郎，本多忠夫，力石国男：海洋波の方向スペクトルについて(続), 第21回海岸工学講演会 諭文集, pp. 261 265, 1974 . 